International Journal of Multi Disipline Science (IJ-MDS)

e-ISSN: 2615-1707 DOI: http://dx.doi.org/10.26737/ij-mds.v1i1.426

International Journal of Multi Disipline Science (IJ-MDS) is licensed under a Creative Commons Attribution-NonCommercial 4.0 International License

\title{
Efforts to Increase through Numeracy Contextual Learning Model in Class III SD
}

\author{
Pebria Dheni Purnasari ${ }^{1}$, Yosua Damas Sadewo ${ }^{2}$ \\ Sekolah Tinggi Ilmu Manajemen Shanti Bhuana ${ }^{1.2}$ \\ pebriadheni@gmail.com,yosua.damas@shantibhuana.ac.id
}

\section{Keywords:}

numeracy, contextual learning model

\begin{abstract}
This research is to improve the numeracy skills through contextual learning model in the third grade students of SDN 10 Melakos. This research is a classroom action research (CAR) conducted jointly with third grade teacher at SDN 10 Melakos, the subject of this study is all third grade students of SDN 10 Melakos totaling 19 students. The data collection techniques is carried out by engineering tests and observation. The results showed that the initial conditions of students who completed their study of $38.84 \%$, and then after being given treatment by applying the model of contextual learning in students who complete the first cycle increased to $68.42 \%$, still well below the thoroughness of performance indicators and after repair on students who complete the second cycle into $89.47 \%$. Their mastery learning students showed that efforts to improve numeracy skills through contextual learning model in the third grade students of SDN 10 Melakos successfully applied.
\end{abstract}

\section{INTRODUCTION}

The ability to count is the ability to be dominated by anyone remember the count has become a means for communication in social life. Fatmawati (2014) states that basically numeracy has been introduced to the students before students enter primary school even if the context is still modest. Aisha et al (2007) explained that numeracy is one ability that is important in everyday life, as shown by the numeracy support all human activities. Thus proving that the conditions numeracy skills must be mastered by everyone. Numeracy basically have begun to be introduced to children as early as possible even before the child knows the school. It shows that numeracy is one of the important skills in life. Noting the importance of numeracy skills in the activities of life, then this ability is one of the goals shall be achieved in education. Ulfah (2013) explained that numeracy is one component of the standard of competence that must be overcome by elementary school students. Numeracy skills are basically a part of the math lesson. Tarin (2006) explains that the purpose of the material exerts arithmetic operations at the primary school level is to form reasoning and attitudes (formal goals) and developing numeracy skills, solve problems and be able to apply mathematical concepts in life (material of interest). Piaget (Suyanto, 2005) states that the objective of learning numeracy for students is to train the ability to think logically and mathematically in a fun and uncomplicated so that students are able to understand and use mathematical language to think not only able to calculate a number of up to one hundred or one thousand. But in fact the math lesson is a lesson that is considered difficult by students. 
Fatmawati (2014) explained that many students have difficulties when learning math, this is because the abstract mathematical properties. The opinion was also expressed by Heruman (2008) which states that the object of study of mathematics has the abstract, so that in teaching it is necessary to apply the model in accordance with the level of students' thinking. This suggests that the study of mathematics has its own difficulty level. Nonetheless, learning math should still be taught, and the concept can be mastered by students. This is as expressed by Marti (Sundayana, 2015) which explains that although mathematics is considered to have a high difficulty, but everyone still have to learn and master the mathematical concept of considering mathematics is a means to solve everyday problems. Difficulties in learning mathematics in particular on the material arithmetic operations also experienced by third grade students of SD 10 Melakos. Through observation and unstructured interviews with some students and teachers, obtained the problems that a lot of students who are having trouble in math. Teachers explained that most students should be taught about the concept of repetitive arithmetic operation, especially on the operations of addition and subtraction. Some students also revealed that math is a difficult subject for them. This demonstrates the ability to count students classified as low, this is reinforced by the results of tests daily tests on the material arithmetic operations summation that of the 19 students, known only 7 students who pass or scored above the KKM (KKM $\geq 65)$, while 12 other students expressed not completed or got under KKM. The completeness of students in the initial conditions can be seen in Table 1 .

Table 1

Mastery Student Class III SDN 10 Melakos Before Measures

\begin{tabular}{llll}
\hline No. & Ketuntasan & Frequency & Percentage \\
\hline 1 & Tuntas & 7 & $36.84 \%$ \\
\hline 2 & TidakTuntas & 12 & $63.16 \%$ \\
\hline Total & & 19 & $100 \%$ \\
\hline
\end{tabular}

The results show that more than 50\% of students have difficulty in mastering the concept of arithmetic summation operation. Thus required an effort to assist students in improving numeracy in particular on the summation of the sum given is the basic concept that is important to be able to master the concepts of multiplication and other concepts. Through the result of reflection by teachers, students are less able to understand the material for the study of mathematics has an abstract object, therefore we need a way of teaching that makes the object abstract to a more concrete. In this case an attempt to do is to apply the model of contextual learning. Johnson (2007) states that the model of contextual learning is a learning model that links academic content to the context of a student's daily life, it helps students to understand the meaning by connecting abstract mathematical concepts with appropriate context. Definition of contextual models is also expressed by Nurhadi (2004) which states that contextual learning model encourages students to be able to connect knowledge with the application of the concept in everyday life. A similar opinion was also presented by Brata (2009: 17) that define the model of contextual learning as learning that emphasizes the linkages between the world of teaching materials with real life, helping students connect and apply the competencies of learning outcomes in everyday life. Understanding shows that contextual models will help students to learn mathematics in a way that is fun and easy to understand.

Noting the problems that have been described, the purpose of this research is to improve numeracy skills in third grade students of SDN Melakos through contextual learning model. 


\section{METHOD}

This research is a classroom action research (CAR) with descriptive approach qualitative and quantitative descriptive. The procedure is carried out in collaboration with classroom teachers, in which the researchers designed a study together with its instrument of accession to be used for further data collection classroom teachers conduct learning activities that have been agreed with the researchers. The steps in the model of CAR in the study described as follows:

1) Conducting observations in order to see the problem.

2) Held discussions with the teacher to obtain the most obvious problems.

3) Provide treatments or treatment of the subject of research classes that perform learning by using learning contextual.

4) Providing the ultimate test in order to determine the increase in students' numeracy skills.

This study was conducted in two cycles, each cycle consisting of the following steps (1) planning, (2) implementation, (3) observation, and (4) reflection. The subjects were all students of class III SDN MelakosBetung River District of West Kalimantan. The number of third grade students of SDN Melakos is 19 students. Data collection technique is to use a test to measure the ability to count and learning activity observation sheet to provide an assessment of the course of the learning process. The type of test used is a kind of essay tests. Furthermore, performance indicators in this study was $80 \%$ of students experiencing learning completeness, meaning that this research is successful if $80 \%$ of the students scored above the KKM $(\mathrm{KKM} \geq 65)$.

\section{RESULTS}

In the initial condition, ie, the condition in which learning with contextual model has not been applied is known that the number of students who completed only reached $38.84 \%$, while students who did not complete reach $63.16 \%$. Seeing a low student mastery efforts are needed to improve the completeness of students in the study improved student mastery learning are thoroughness numeracy. By paying attention to these conditions, the action research done by applying a contextual model. In the first cycle of learning activities can be taught quite well, although there are some learning activities which in practice is less than the maximum. Through reflection on learning in the first cycle is done with the help of observation sheets teachers and students then can be some advantages and disadvantages of learning during the first cycle of the implementation, teacher explanation regarding instructional materials less profound, students are still having trouble connecting context for learning abstract to the real. The material taught in the first cycle is the sum arithmetic operations. Teachers also less than the maximum in the use of learning resources, so that the student is still difficult to understand what is learned. Such a condition becomes reflection and material improvements in the second cycle.

Furthermore, on learning with the second cycle, the teacher is able to convey a good learning. Students are able to follow the lesson with the teacher. Teachers were able to convey the material by utilizing learning resources that help students understand the material. Teachers also give more students the opportunity to express their opinions or ask questions. It is very encouraging students to develop numeracy skills. Through contextual learning that is designed to help students to more easily understand the material being taught. Counting more fun activities. Material reduction arithmetic operations can be delivered either through modeling performed by the teacher, it gives an overview on the students so that students are able to understand the concept of subtraction. Students also had no difficulty in connecting the real context to the context of the abstract in mathematics. These conditions correspond to the characteristics of mathematics learning. Bruner (Heruman, 2008) states 
that in mathematics is required activities that make students discover for themselves what it needs. The conditions being the case, we need a model of learning that match the characteristics of mathematics learning one of them is a contextual model. Rusman (2010) explains that contextual learning enables students to find their own concept for learning that is designed to help students connect concepts with real-world teaching materials that help students understand the material. Learning with contextual help his students learn with their modeling material that connects the real world making it easier for students to understand the material, it would affect the students' learning outcomes. Here is shown an assessment of learning activities through teacher observation sheet.

Table 2

Rate Observation Teacher

\begin{tabular}{|c|c|c|c|c|c|c|c|c|c|}
\hline \multirow{3}{*}{ No. } & \multirow[t]{3}{*}{ Activity Teacher observed } & \multicolumn{4}{|c|}{ Cycle I } & \multicolumn{4}{|c|}{ Cycle II } \\
\hline & & \multicolumn{2}{|c|}{$\begin{array}{l}\text { Meeting of the } \\
\text { I }\end{array}$} & \multicolumn{2}{|c|}{ Meeting II } & \multicolumn{2}{|c|}{ Meeting I } & \multicolumn{2}{|c|}{ Meetings II } \\
\hline & & Yes & No & Yes & No & Yes & No & Yes & No \\
\hline 1 & $\begin{array}{l}\text { Explain the purpose of } \\
\text { learning or basic } \\
\text { competencies that need to be } \\
\text { achieved }\end{array}$ & $\begin{array}{l}\sqrt{ } \\
\sqrt{ }\end{array}$ & & & & & & $\sqrt{ }$ & \\
\hline 2 & $\begin{array}{l}\text { Delivering } \\
\text { Content andStrategy } \\
\text { Learning }\end{array}$ & & $\sqrt{ } \sqrt{ }$ & & & & & $\sqrt{ }$ & \\
\hline 3 & $\begin{array}{l}\text { Use of the Model } \\
\text { Study and } \\
\text { Utilization ofResources } \\
\text { Learning }\end{array}$ & & $\sqrt{ } \sqrt{ }$ & & & & & $\sqrt{ }$ & \\
\hline 4 & $\begin{array}{l}\text { assessment } \\
\text { of Learning Outcomes }\end{array}$ & $\begin{array}{l}\sqrt{ } \\
\sqrt{ }\end{array}$ & & & & & & $\sqrt{ }$ & \\
\hline 5 & $\begin{array}{l}\text { Ending } \\
\text { Lessons }\end{array}$ & $\begin{array}{l}\sqrt{ } \sqrt{ } \\
\sqrt{ }\end{array}$ & & & & & & $\sqrt{ }$ & \\
\hline & Total & 3 & 2 & 4 & 1 & & & $5-5$ & - \\
\hline
\end{tabular}

Noting Table 2 which recaps judgment on the observation sheet teachers the use of contextual models in learning Mathematics, it is known that in the first cycle of the first meeting, from 5 activities that need to be done using a contextual model, there are two activities are missed. At the second meeting of the first cycle, an increase of 5 stars based model of contextual learning activities, 4 activity can be implemented well and there is only one activity is missed. Conditions are getting better shown through the second cycle I and II meetings that overall activity is able to be performed well.

Observations were also performed on students in learning activities through observation sheet of students. This observation is intended to determine the extent to which students are able to follow the model of contextual learning. Here, presented a recap of assessment of student observation sheet. 
Table 3

Assessment Observation Student

\begin{tabular}{|c|c|c|c|c|c|c|c|c|c|}
\hline \multirow{3}{*}{ No } & \multirow{3}{*}{ Activities Students observed } & \multicolumn{4}{|c|}{ Cycle I } & \multicolumn{4}{|c|}{ Cycle II } \\
\hline & & \multicolumn{2}{|c|}{$\begin{array}{l}\text { Meeting of the } \\
\text { I }\end{array}$} & \multicolumn{2}{|c|}{ Meeting II } & \multicolumn{2}{|c|}{ Meeting I } & \multicolumn{2}{|c|}{ Meetings Il } \\
\hline & & Yes & No & Yes & No & Yes & No & Yes & No \\
\hline 1 & $\begin{array}{l}\text { Students listen to the learning } \\
\text { objectives }\end{array}$ & $\begin{array}{l}\sqrt{ } \sqrt{ } \\
\sqrt{ }\end{array}$ & & & & & & $\sqrt{ }$ & \\
\hline 2 & $\begin{array}{l}\text { Students pay attention to the } \\
\text { explanation of material } \\
\text { performed by the teacher with } \\
\text { modeling }\end{array}$ & & $\sqrt{ } \sqrt{ }$ & & & & & $\sqrt{ }$ & \\
\hline 3 & $\begin{array}{l}\text { Students associate with } \\
\text { modeling material presented } \\
\text { teachers. }\end{array}$ & & $\sqrt{ } \sqrt{ }$ & & & & & $\sqrt{ }$ & \\
\hline 4 & $\begin{array}{l}\text { Students investigate and find the } \\
\text { concept by collecting, } \\
\text { organizing, perinterpretasian } \\
\text { data in an activity that has been } \\
\text { designed by teachers }\end{array}$ & & $\sqrt{ } \sqrt{ }$ & & & & & $\sqrt{ }$ & \\
\hline Total & & 1 & 3 & 2 & 2 & 3 & 1 & 4 & - \\
\hline
\end{tabular}

Table 3 shows a recap of assessment of student observation sheet. At the first meeting and the second cycle I showed that out of four learning activities with contextual model there is only one activity that is done, all three other events have not been implemented to the fullest. It is caused by several things, namely teachers less than the maximum leverage in applying the contextual model, teachers are not given the opportunity for students to ask questions or express opinions, so students did not show any material that has not been conceived as a result students have not understood properly in learning Mathematics, However, these conditions, but coped well at the meeting and the next cycle, this is indicated by an increase in assessments on student observation sheet as shown in Table 3 .

The existence of the success in the implementation of learning by applying a contextual model shows that this model can be applied and followed by students well. To see an increase in student numeracy skills, then the assessment using tests. The test is given at the end of each cycle to see that how the numeracy skills in students. Based on the test results of the first cycle it can be seen that the number of students who pass or scored above the KKM there are as many as 13 students with a percentage of $68.42 \%$ and students who did not complete its worth there are 6 students or by $31.58 \%$. This indicates that the completeness of students in the first cycle is better than the condition before the action in which students are not completely reached $66.16 \%$ and students who completed only $38.84 \%$. These results showed an increase of conditions before being given to the first cycle of action, but despite an increase in the thoroughness of the first cycle is still below the performance indicators of completeness is still below $80 \%$. The completeness in the first cycle that has not reached the performance indicators in this study due to learning that do not maximized. This condition is evidenced by the assessment of learning on the observation sheet teachers and students also show the results have not been up. After reflection and designed improvements then, applied learning in the second cycle. Similarly, numeracy assessment in the first cycle, the second cycle was also given a test at the end of the cycle to determine the ability to count on the students. Through analysis of the numeracy test results it can be seen that the number of students who completed the second cycle reaches $(89.47 \%$ ), while students who did not complete was reduced to 2 students or equivalent (10.53\%). This indicates an increase in completeness of student learning outcomes of the first cycle and also to a prior action, namely to a prior act of students who completed only $38.84 \%$ increase to $58.42 \%$ in the first cycle and increased again to $89.47 \%$. The existence of this increase also shows that students who did not complete also decreased from $63.16 \%$ in the initial condition was reduced to $31.58 \%$ in the first cycle, anddecreased again to $10.53 \%$. Although in the second cycle there are students who do not complete, but mastery learning in the second cycle also has achieved the 
specified performance indicators so this research is successful. Furthermore, for the two students who did not complete the counseling conducted independently so that does not impede other students who have completed and the learning process is not interrupted and can be continued at the next material is not examined in this PTK. The student's mastery numeracy skills can be seen in Figure 1.

Ketuntasan Kemampuan Berhitung

$*$ Tuntas $=\frac{2}{\text { Tidak Tuntas }}$

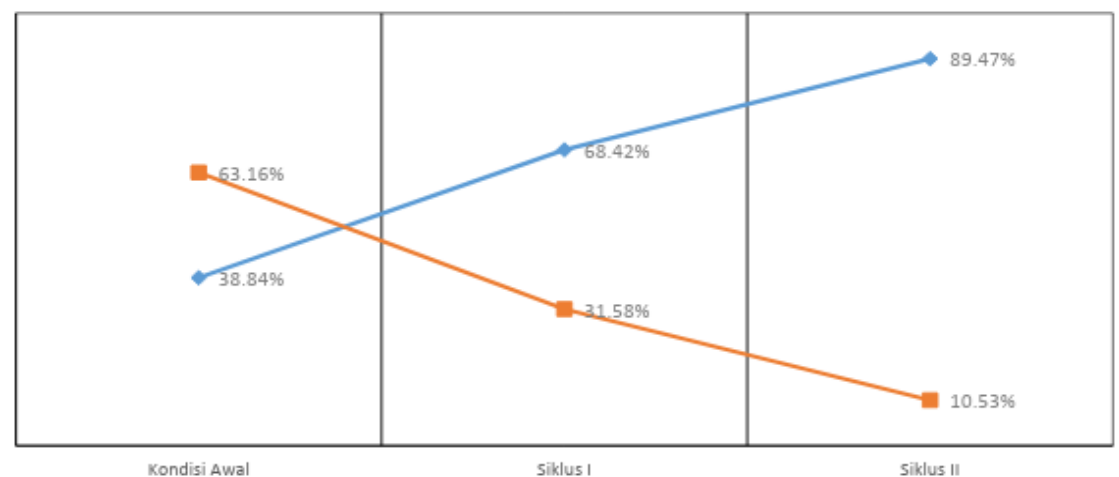

Figure 1. Complete Ability to Count On Initial Conditions, Cycle I, Cycle II

results support this study supports the results of research conducted by Nur and Sulthoni (2015) where the research results show the influence positive between contextual learning model with numeracy skills in students. Similar results were shown by Sutinah (2013) and Afif (2010) in which both successfully demonstrated that a contextual model can improve student learning outcomes. Success in this study suggest that contextual model was able to make mathematics more enjoyable. This is supported by the component in contextual learning model, namely constructivism, find, asking, learning community, modeling, reflection, and real penialian (Rusman, 2010). The components are then applied in the design of learning in this study. At this stage of constructivism, teachers build or construct new knowledge to the students by asking the materials studied in the first cycle of the materials studied is the arithmetic operations of addition and the second cycle is the reduction arithmetic operation. Teachers build concept by linking objects around with the material being studied through the questions, so that students understand and find the concept in their own way. At tAHAPinquiry or find applicable in the task of giving the students got a problem in which students observe and manipulate certain objects to complete a given task. Phase ask is that point where, students are given the opportunity to ask questions related to the problem given by the teacher, the next stage of learning communities conducted in the reporting of results. Activity reporting of results is a form of learning community stage, at this stage the students were asked to indicate the outcome of a matter that is resolved. Permodelam stage is the stage in which the teacher gave a demonstration on how to observe and manipulate objects in the right way, at this stage teachers also guide students to relate what they have learned into everyday life. Phase of reflection is in the form of making a conclusion, students are led to conclude that the material has been studied. Components of the latter on contextual learning model is judging, teachers assess students' abilities. Ratings are given individually through an evaluation test at the end of the cycle. These results are in line with the opinion of Johnson (2009), which explained that the contextual model is a learning process that connects the teaching material in the context of everyday life of students making it easier for students to understand the material being taught. These conditions make the students become excited and motivated to learn so the impact on improving student learning outcomes. 


\section{CONCLUSION}

From the entire implementation of the action research using a model of contextual learning in Mathematics matapelajaran third grade students of SDN 10 Melakos the second semester of academic year 2017/2018, it can be concluded that the use of contextual learning model can improve numeracy skills of students especially material arithmetic operations of addition and subtraction. This is evidenced by an increase in the thoroughness of the initial conditions to the second cycle. In the initial condition of complete student learn as much as 7 students (38.84\%) of the 19 students. After learning improvements implemented in the first cycle, the number of students who pass the study to 13 students (68.42\%). In the second cycle, it is known that the number of students who completed the study were 17 students $(89.47 \%)$. Based on these results it is said that learning with contextual learning model can improve numeracy skills as planned.

\section{REFERENCES}

Afif, Mokhamad. Thesis 2010. Efforts to Increase Motivation Mathematical Model of Contextual Teaching and Learning (CTL) Students of Class V SDN Sumbaga 02 Bumijawa District of Tegal Year 2009/2010. Essay. Surakarta: UNS.

Aisha, N. 2007. Development of Elementary Mathematics Education. Jakarta: Dikjen Higher Education.

Brata. 2009. Understanding Approach. Strategies, Methods, Techniques, Tactics, and Learning Model. http://mbahbrata-edu.blogspot.co.id/2009/12/pengertian-pendekatan-strategi-metode.html. Accessed on December 18, 2017

Fatmawati, N. 2014. Upgrades Numeracy Through Realistic Approach Mathematic Education. Journal of Early Childhood Education, 8 (2): 315 - 326.

Heruman. 2008. Mathematical Learning Model PrimarySchools.Bandung: Youth Rosdakarya.

Johnson, B. 2009. ElanieContextual Teaching \&Learning.Bandung: MLC.

Nur, DLK, and Sulthoni. 2015. Effect of Contextual Learning to Count Reduction Capabilities Against Mentally Retarded Students of Class 4. JunralOrtopedagogia, 1 (4): 302 - 307.

Nurhadi. 2004 Contextual Learning (Contextual Teaching and Learning / CTL) and application in the CBC. Malang: UM.

Rusman. 2010. Models Developing Professional TeacherEducation.Jakarta: PT RajaGrafindoPersada.

Sundayana, R. 2014. Media Viewer tool in Learning Mathematics.Bandung: Alfabeta.

Sutinah. Thesis 2013. Efforts to Improve Learning Outcomes In Operation Addition Math Fractions Through Contextual Teaching and Learning (CTL) At Grade IVB Min KebonagungImogiri Bantul. Essay. Yogyakarta: UIN SunanKalijaga.

Suyanto, S. 2005. Fundamentals of Early Childhood Education. Jakarta: Hikayat.

Tarin, D. 2006. Realistic Mathematics Education. Jakarta: Directorate General of Higher Education Ministry of Education.

Ulfah, A. 2013. Efforts to Improve Ability Numeracy Grade III SD Through Media Games "Debt". Diktatika Journal, 4 (1): 402-414. 